Original Research Paper

\title{
Utilization of Holt's Forecasting Model for Zakat Collection in Indonesia
}

\author{
${ }^{1}$ Akbarizan, ${ }^{2}$ Muhammad Marizal, ${ }^{2}$ M. Soleh, ${ }^{1}$ Hertina, \\ ${ }^{1}$ Mohammad Abdi. A., ${ }^{2}$ Rado Yendra and ${ }^{3}$ Ahmad Fudholi \\ ${ }^{1}$ Department of Law and Syari'ah, \\ Universitas Islam Negeri Sultan Syarif Kasim (UIN Suska), 28293, Pekanbaru, Riau, Indonesia \\ ${ }^{2}$ Department of Mathematics, Faculty of Science and Technology, \\ Universitas Islam Negeri Sultan Syarif Kasim (UIN Suska), 28293, Pekanbaru, Riau, Indonesia \\ ${ }^{3}$ Solar Energy Research Institute, Universiti Kebangsaan Malaysia, 43600 Bangi, Selangor, Malaysia
}

Article history

Received: 11-08-2016

Revised: $20-12-2016$

Accepted: 22-12-2016

Corresponding Author:

Akbarizan

Department of Law and

Syari'ah, Universitas Islam

Negeri Sultan SyarifKasim

(UIN Suska), 28293Pekanbaru,

Riau, Indonesia

Email: akbarizan@uin-suska.ac.id

\begin{abstract}
The practice of zakat is gaining popularity in Indonesia. This development is attributed to the strong role of the government in consistently developing zakat infrastructure and the increased awareness of people to practice zakat. Despite this success, a mechanism for predicting future zakat collection has not yet been developed. This study applies Holt's exponential smoothing and Auto-Regressive Integrated Moving Average (ARIMA) model to forecast zakat in Indonesia using zakat collection from 2009 to 2014. Results show that Holt's exponential smoothing is best fits the zakat time series data and is therefore suitable for forecasting zakat. Holt's exponential smoothing is comparable to the ARIMA model given its small deviations in mean absolute percentage error and mean square error. Moreover, the software used to implement Holt's exponential smoothing is similar to that used in ARIMA models. These similarities show that these models can accurately forecast future trends to prepare proper strategies and plan the future of the organization. These models can also be used to develop a plan for managing charity based on the number of recorded mustahiq.
\end{abstract}

Keywords: Holt's Exponential Smoothing, Forecasting, Zakat, Trend

\section{Introduction}

Islam is a complete religion that teaches Muslims how to perform shalat and how to help others by giving through zakat. Zakat is frequently mentioned in the Holy Qur'an after the word shalat, which implies that zakat is equally important as shalat. This concept suggests that Islam requires Muslims to obey Allah vertically through shalat and to help each other horizontally or economically by paying zakat. "Zakat", which literally means "that which purifies" or alms, is the act of giving a fixed portion of one's wealth to charity, generally to the poor and needy. Zakat is the most appropriate methodology in Islamic concept for solving social issues, such as poverty. Zakat is observed by sharing a percentage of wealth to qualified recipients. According to Syariah rules and guidelines, zakat is an obligation of a Muslim who can afford to pay. Zakat refers to the practice of spending a fixed portion of one's wealth for the poor and the needy. Zakat differs from ordinary forms of charity because it is an obligation imposed on all Muslims. Moreover, the amount of zakat contribution is calculated. Most Muslim countries at present collect zakat through a decentralized and voluntary system. Zakat committees are established under this voluntary system. Zakat committees play an integral role in collecting donations from the community and distributing these donations to the needy. Zakat also plays an important role in society by preserving social harmony between the wealthy and the poor. The Indonesian government established a zakat center in every state to facilitate the management of zakat. The effectiveness of zakat collection and distribution is highly dependent on the management of zakat centers. The centers should be equipped with an effective zakat management system to facilitate the execution of the center's functions, especially in the collection and distribution of zakat. However, most zakat centers lack an effective method of managing zakat collection and distribution. These centers require a good forecasting 
model. Forecasting can help zakat centers conduct precise approximation of future zakat collection and distribute these collections appropriately. Moreover, advance knowledge of the predicted value of zakat collection can help management to plan a strategy to achieve their target.

Research on zakat has increased since 2009. Despite this increase, only a few studies have focused on the prediction of zakat collection. To address this gap, the present study proposes methods of calculating zakat collection in Indonesia. Out method applies univariate analysis and uses past zakat collections as data input. Univariate method was adopted because of unavailability of important data that may determine zakat collections, such as the income earned by Muslims, the number of Muslims pay taxes and the amount of taxes paid. Another issue is the lack of institution that collects data on zakat collection in a monthly basis. We rely on past data to address these limitations. We use zakat collected by an amil zakat, namely, Rumah Zakat. This study examines available data on zakat collections. We use statistical tools and we accommodate seasonality and growth to determine the most accurate prediction of future zakat collections based on available data. The method used in this study is double exponential smoothing or Holt's forecast model.

Only a few studies examined the calculation method of zakat. However, several studies explored the management of zakat institutions. These studies examined strategies to increase people's awareness of zakat, distribute zakat through programs that empower people with low income and approaches in managing zakat (Hudayati and Tohirin, 2010). Existing studies also discussed the importance of zakat as a tool of income distribution in a normative way.

To the best of the author's knowledge, Osman (2007) is the only study conducted in Malaysia that examined zakat payers and zakat collection; this study also explored zakat in relation to income and trading. This study involved three steps. First, the number of Muslim population in Malaysia was obtained. Second, Muslims who are eligible to pay zakat were identified. Thirdly, potential zakat collections were calculated.

Forecasting involves estimating the future values of variables of interest using past and current information. Given the complexity of forecasting, this field attracted attention from several researchers. Existing studies employed several forecasting methods, which include Auto-Regressive Integrated Moving Average (ARIMA), exponential smoothing, Artificial Neural Network (ANN) and logistic regression (Shamsuddin et al., 2008). Research on zakat forecasting also compared several forecasting methods, such as linear time series methods, which include ARIMA, moving average, exponential smoothing and decomposition. The present study discusses Holt's forecasting method or the double exponential smoothing model. The double exponential smoothing model is a reasonable method for in-sample forecasts. However, this method should not be used for long-term forecast. This method may produce a good forecast in short lead time only, such as one or two periods ahead (Sukmana and Heri, 2011).

\section{Research Methodology}

Practically, the classic method used by practitioners in any field involving trendline, Auto-Regressive Integrated Moving Average (ARMA) and time series. We adjust this prediction method used in this study and at the same time we compare these methods. In the world of forecasting, neural networks are commonly used in various applications. In this study, we use methods ARIMA and Holt's model to forecast earnings zakat in Indonesia's future using past data. The results of the exercise were compared with the results obtained through the implementation of the classical rules based on the Root Mean Square Error (RMSE). In order to forecast the results of forecasting either or appropriate to note the pattern of the data and methods used. One method that can be used for forecasting time series data that Exponential Smoothing Methods Dual and Exponential Smoothing Methods for data Patterned Dual Linear trend. In terms of forecasting, forecast accuracy in the future is the most important because it will show how far a model fits the past data available. One way to measure the accuracy of forecasting by calculating the average value of the Absolute Percentage Error (MAPE). The smaller the value of MAPE obtained the results of the forecast is getting better.

Let $Y_{1}, Y_{2}, \ldots, Y_{n}$ be a set of observatioans on a nonseasonal time series. The Holt's model is based on estimating smoothed versions of the level and the trend of the time series. The level plus the trend is then extrapolated forward to obtain the forecast. The formulas governing of the level and the trend are given by (Brooks, 2008; Jere and Siyanga, 2016). The following procedure to forecast non-seosonal series.

1.The first step is to obtain level estimate and trend estimate represented by and respectively as:

$$
\hat{Y}_{t}=Y_{2}, \quad T_{2}=Y_{2}-Y_{1}
$$

These estimates can also be determined by fitting a least squares trend line to half of the historical data. In the following equations, $y$ intercept is and slope is:

$$
\begin{array}{ll}
A_{t}=\alpha Y_{t}+(1-\alpha)\left(A_{t-1}+T_{t-1}\right) & (0<\alpha<1 ; t=1.2 . \cdots, n) \\
T_{t}=\beta\left(A_{t}-A_{t-1}\right)+(1-\beta) T_{t-1} & (0<\beta<1 ; t=1,2, \cdots, n)
\end{array}
$$


The value of $\alpha$ and $\beta$ that minimizes Mean Square Error (MSE) is preferred. These values are calculated using the solver in $\mathrm{R}$.

2. The forecast of future values $\hat{Y}_{t+p}$ of the series can be obtained by:

$$
\hat{Y}_{t+p}=A_{t}+p T_{t} \quad(p=1,2,3, \cdots, k)
$$

where, $p$ is the number of periods in the future.

\section{Data Analysis, Results and Discussion}

In this study, the source of the data is the site Rumah Zakat of Indonesia is reported by the statistics Indonesia. The data used in the analysis is that of the zakat collection from 2009 to 2014. Figure 1 shows that the plotted time series has an upward trend or strong increasing. The source of these data is the Rumah Zakat of Indonesia site, which is reported by statistics in Indonesia.

The average collection of zakat in Indonesia from 2009 to 2014 amounted to $\operatorname{Rp} 58,528,745,634$. An

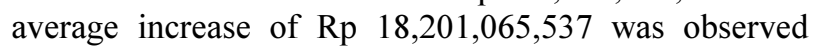
from the previous year. The increased zakat collection in of zakat in Indonesia can be attributed to the growth of Muslim population in this country or the increased awareness of Muslims of the importance of donating to charity and helping the less fortunate. Forecast for the following year can be determined by fitting the appropriate model.

\section{Limitation using Holt's Exponential Smoothing}

Holt's exponential smoothing can be used if the time series can be described using increasing or decreasing trend without seasonality. The zakat collection data used in this study demonstrated increasing trend without seasonality. These data are shown in Fig. 1. Why did we employ Holt's exponential smoothing to make forecasts?

\section{Holt's Exponential Smoothing Model}

The trend of the time series plot of zakat collection in Indonesia plotted in Fig. 1 has no seasonal pattern and growth rate changes over time. Given these features, Holt's exponential smoothing method was adopted to forecast future values of inflation.

First, we obtained the initial estimates of $A_{0}$ and $T_{0}$ by:

$$
\hat{Y}_{1}=A_{0}+T_{0}
$$

where, $A_{0}=Y_{1}$ is the $y$ intercept and $T_{0}=\left(Y_{2}-Y_{1}\right)+\left(Y_{4^{-}}\right.$ $\left.Y_{3}\right) / 2$ is the slope.

Second, the calculations of the smoothed level estimates $A_{t}$, smoothed trend estimates $T_{t}$, forecast value
$\hat{Y}_{t}$, forecast error $\varepsilon_{t}$ and squared forecast error $\varepsilon_{t}^{2}$ at time $t$ (where $t=1,2, \ldots, n)$ were performed using predetermined values of smoothing constants $\alpha$ and $\beta$. Solver in $\mathrm{R}$ was used to determine the best combination of $\alpha$ and $\beta$ that minimizes MSE. The values of $A_{t}, T_{t}, \hat{Y}_{t}, \varepsilon_{t}$ and $\varepsilon_{t}^{2}$ were updated using the new values of $\alpha$ and $\beta$ (i.e., $\alpha=0.5294$ and $\beta=$ $0.9999)$. These values were chosen based on the combination that minimizes the MAPE and RMSE. The fitted model was given as:

$$
A_{t}=(0.5294) Y_{t}+(0.4706)\left(A_{t-1}+T_{t-1}\right)
$$

And:

$T_{t}=0.9999\left(A_{t}-A_{t-1}\right)+(0.0001) T_{t-1}$

and $\hat{Y}_{t+p}$ follow Equation 3. The estimation for the MAPE and RMSE are:

$$
\begin{gathered}
M A P E=\frac{100}{n} \sum_{t=0}^{n} \frac{\left|Y_{t}-\hat{Y}_{t}\right|}{Y_{t}}=0,25015 \\
M S E=\frac{1}{n} \sum_{t=0}^{n}\left(Y_{t}-\hat{Y}_{t}\right)^{2}=2169,965
\end{gathered}
$$

And:

$$
R M S E=\sqrt{2169,965}=4.658,288
$$

The updated values of $A_{t}, T_{t}, \hat{Y}_{t}, \varepsilon_{t}$ and $\varepsilon_{t}^{2}$ are summarized.

\section{Forecast Using Holt's Exponential Smoothing Model}

A five-step forecast was conducted at time $\mathrm{t}$ for zakat collection. The equation below is used to calculate forecasted $p$ until $k$ step ahead of zakat collection:

$\hat{Y}_{t+p}=A_{t}+p T_{t}$

where, $p$ is the number of steps ahead.

Table 1 shows summarizes the forecasting results of the Holt's Double Exponential Smoothing method of zakat for one year ahead forecast from 2009 to 2014 .

Figure 2 shows the time plot of the actual, fitted and one year forecast for zakat collection using the Holt's double exponential smoothing with 95\% confidence interval. It can be seen that all the forecasted values fall within the confidence interval which shows the level of accuracy. 


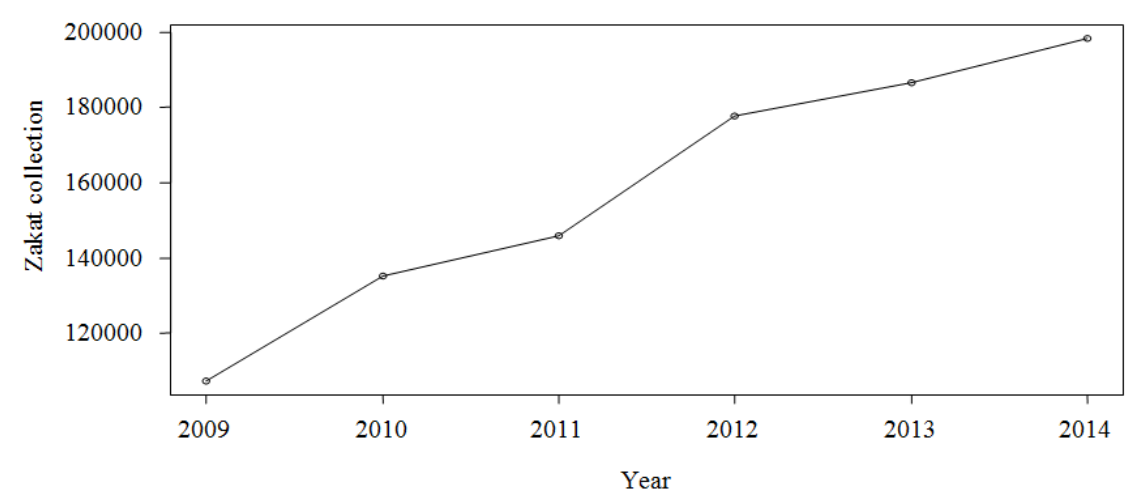

Fig. 1. Time series plot of zakat collection (in million Rupiah) from 2009 to 2014

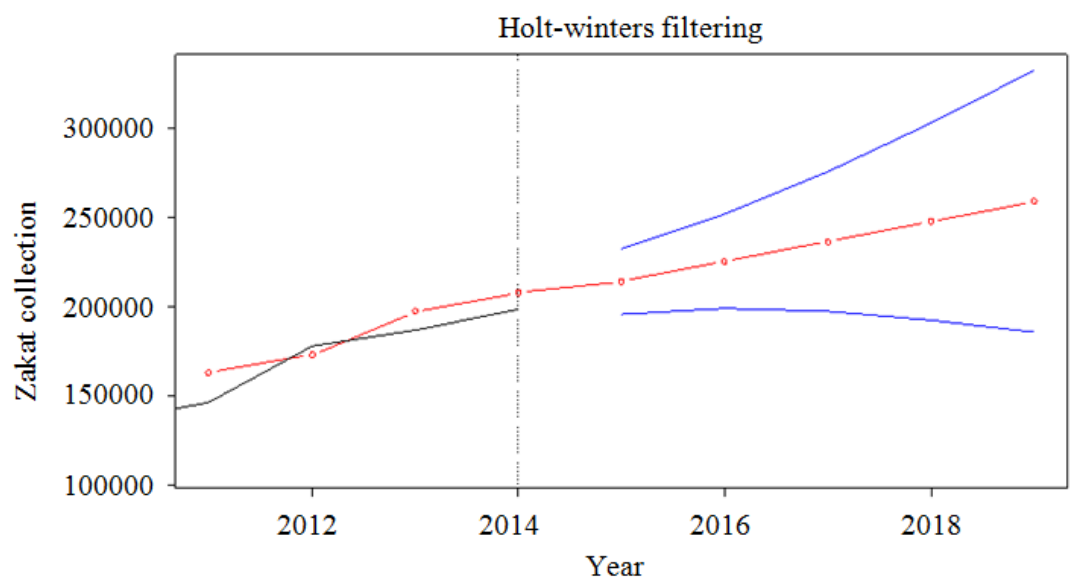

Fig. 2. Forecasting results using Holt's method (in million Rupiah)

Table 1. Holt's forecast model (double exponential smoothing)

\begin{tabular}{|c|c|c|c|}
\hline Year & Zakat collection (Rp) & Forecast (Rp) & \\
\hline 2009 & 107.326 .409 .633 & 0 & \\
\hline 2010 & 135.081 .733 .578 & 135.081 .733 .578 & \\
\hline 2011 & 145.871 .342 .558 & 162.837 .057 .523 & \\
\hline 2012 & 177.810 .761 .563 & 164.278 .557 .557 & \\
\hline 2013 & 186.750 .489 .158 & 202.656 .278 .072 & \\
\hline 2014 & 198.331 .737 .316 & 203.643 .848 .216 & \\
\hline 2015 & - & 211.343 .775 .933 & $p=1$ \\
\hline 2016 & - & 224.037 .087 .896 & $p=2$ \\
\hline 2017 & - & 236.730 .399 .859 & $p=3$ \\
\hline 2018 & - & 249.423 .711 .822 & $p=4$ \\
\hline 2019 & - & 262.117 .023 .785 & $p=5$ \\
\hline
\end{tabular}

Table 2. Comparison of Holt's exponential smoothing and ARIMA forecasting for zakat collection data (in million Rupiah)

\begin{tabular}{llll}
\hline & $\begin{array}{l}\text { Forecast of } \\
\text { Zakat-Holt's Model }\end{array}$ & $\begin{array}{l}\text { Forecast of } \\
\text { Zakat ARIMA Model }\end{array}$ & $\begin{array}{l}\text { Deviationsin } \\
\text { forecastof zakat }\end{array}$ \\
\hline 2015 & $213.931,8$ & $195.822,7$ & $18.109,10$ \\
2016 & $225.137,0$ & $188.496,9$ & $36.640,10$ \\
2017 & $236.342,1$ & $177.270,1$ & $59.072,00$ \\
2018 & $247.547,3$ & $166.159,0$ & $81.388,30$ \\
2019 & $258.752,4$ & $157.239,1$ & $101.513,30$ \\
MAPE & 0,25015 & 0,34926 & $(0.09911)$ \\
RMSE & $4.658,288$ & $5.456,368$ & $(804,08)$ \\
\hline
\end{tabular}


Figure 2 shows that the resulting values approached the actual forecast. This finding indicates that the model that used Holt's smoothing constants is suitable for forecasting zakat collection in Indonesia.

\section{ARIMA Model}

After applying the Box-Jenkins methodology, an ARIMA ((12), 1, 0) model was chosen using Statistical Analysis System (SAS) (SAS Institute Inc, 2014).

By using backshift operator $\mathrm{B}$, the mathematical form of the estimated value is given as $\sigma^{2}=29.771 .955$.

\section{Forecasting with the ARIMA ((12), 1, 0) Model}

Table 2 shows a summary of the forecasting results of zakat from 2015 to 2019 . The corresponding zakat of this period was calculated using the forecasted zakat collection values and small deviations in the forecast of inflation between Holt's method and ARIMA model.

One purpose of income forecasting model for zakat collection in Indonesia is to achieve managementrelated targets in the collection and distribution of zakat. Table 1 shows the amount of zakat collection and distribution forecasts from 2015 to 2019 . Figure 2 also shows a sketch of the actual and forecasted collections from 2015 to 2019 . The graph shows a predictive value with a yearly upward trend.

We determined the forecasted zakat revenue for next year, but we failed to identify zakat potential in Indonesia because of unavailability of other important variables. To address this gap, the government should impose a policy that requires zakat institutions to submit data regularly to an appointed body.

\section{Conclusion}

Zakat collection in Indonesia was forecasted using zakat collection data from 2009 to 2014. Holt's exponential smoothing method and ARIMA model were used to forecast zakat. The forecasted results summarized in Table 2 indicate that Holt's exponential smoothing method best fits zakat time series data. Thus, this method is suitable for forecasting zakat. The ARIMA model is also suitable for predicting zakat collection because of small deviations in RMSE and MAPE. However, unlike the ARIMA model, Holt's exponential smoothing model is less complicated because it does not require the use of specialized software for implementation. Thus, the parties responsible for collecting zakat can indicate a reasonable target for future zakat collection. They can also plan to distribute alms based on their goals. Moreover, the information supplied indirectly increases the efficiency of handling zakat collection.

\section{Acknowledgement}

The authors acknowledge the support of the UIN Suska Pekanbaru, Riau, Indonesia.

\section{Authors' Contributions}

Akbarizan: Design concept, data interpretation and writing of the paper.

Muhammad Marizal: Execution of simulation model.

M. Soleh: Execution of simulation model.

Hertina: Review and data collection.

Mohammad Abdi. A: Review and data collection.

Rado Yendra: Contribute to data interpretation and writing of the paper.

Ahmad Fudholi: Revise, improve and critical review of the paper.

\section{Ethics}

This study is contains unpublished material and original, also no ethical issues are involved.

\section{References}

Brooks, C., 2008. Introductory Econometrics for Finance. 2nd Edn. Cambridge University Press, Cambridge, ISBN-10: 1139472305.

Hudayati, A. and A. Tohirin, 2010. Management of zakah: Centralised Vs decentralised approach. Proceedings of the 7th International Conference-the Tawhidi Epistemology: Zakat and Waqf Economy, (ZWE'10), Bangi, pp: 351-374.

Jere, S. and M. Siyanga, 2016. Forecasting inflation rate of Zambia using Holt's exponential smoothing. Open J. Statist., 6: 363-372. DOI: 10.4236/ojs.2016.62031

Osman, A.H.A., 2007. Potensi pembayar dan kutipan zakat di Malaysia. Persidangan Zakat dan Cukai Peringkat Kebangsaan 2007 Kuala Lumpur.

SAS Institute Inc, 2014. SAS/ETS 13.2 User's Guide: The ARIMA Procedure. SAS Institute Inc., Cary.

Shamsuddin, S.M., R. Sallehuddin and N.M. Yusof, 2008. Artificial neural network time series modeling for revenue forecasting. Chiang Mai J. Sci., 35: 411-426.

Sukmana, R. and K. Heri, 2011. Univariate time series analysis: Methods for calculating zakat collections potential in Indonesia. Proceedings of the International Zakat Conference (I ZC' 11), IPB Bogor Indonesia, Bogor. 